\title{
STRATEGI PENGEMBANGAN PARIWISATA BERBASIS MASYARAKAT DI PULAU SAMALONA, MAKASSAR
}

\author{
Nurdin \\ Prodi Magister Kajian Pariwisata Universitas Udayana \\ Sekolah Tinggi Pariwisata Tamalatea Makassar \\ Email: nunostipar@gmail.com
}

\begin{abstract}
Samalona Island is one of the tourist destinations in Makassar. Therefore it needs an effective strategy for the tourism development by empowering local communities. The research aims were identifying and analyzing potency and tourist attraction, community participation and formulate development strategies. This research applied theory of tourism area life cycle, theory of planning and theory of participation. The data were collected by documentation studies, observation and in-depth interviews. Data were analyzed by descriptive qualitative method and matrix SWOT. The results suggested that Samalona Island is very feasible to be developing as a community-based tourism destination with the natural and socio-cultural potencies. The development of those obstacles are by applied strategies are as follows; strategy of strengthopportunity $(\mathrm{S}-\mathrm{O})$ with development strategy of tourism destination and development strategy of tourism attraction, strategy of strength-threat $(\mathrm{S}-\mathrm{T})$ with improvement strategy of environmental quality, development strategy of sustainable tourism, strategy of weakness-opportunity (W-O) with promotion strategy of tourism destination, whereas strategy of weakness-threat (W-T) with development strategy of human resources and development strategy of institutional and management of destination.
\end{abstract}

Keywords: strategy, development, community-based tourism, Samalona Island

\section{Pendahuluan}

Perkembangan industri kepariwisataan saat ini diidentifikasi terdapat pergeseran orientasi, dari mass tourism menuju ke alternative tourism. Hal tersebut terjadi karena adanya perubahan orientasi pasar yang lebih menekankan kepada penghayatan dan penghargaan terhadap aspek kelestarian alam, lingkungan dan budaya (enviromentally and cultural 
sensitives), dengan penerapan pariwisata alternatif (alternative tourism). Ukuran keberhasilan pembangunan pariwisata yang menggunakan konsep berkelanjutan tidak hanya dari aspek ekonomi (meningkatnya devisa) yang ditentukan dengan lama kunjungan (lenght of stay) serta eksploitasi lingkungan untuk kegiatan kepariwisataan, namun dari kelestarian dan pemberdayaan sebagai landasan, yang mengarah pada kelestarian lingkungan dan sumber daya alam serta nilai sosiokultural kemasyarakatan dengan penghargaan yang tinggi (Kemen LH, 2003)

Pariwisata Indonesia adalah pariwisata yang berasal dari, oleh dan untuk rakyat, untuk itu dalam perencanaan pengembangan pariwisata harus melibatkan masyarakat setempat (lokal) khususnya yang berada di sekitar destinasi wisata, karena masyarakat setempat merupakan pemilik dan lebih mengetahui destinasi tersebut (Ridwan, 2012).

Penerapan pariwisata berbasis masyarakat atau community based tourism (CBT) merupakan suatu pendekatan pembangunan pariwisata dengan perencanaan yang partisipatif. Definisi CBT yaitu: model pariwisata yang melibatkan masyarakat lokal dengan memberi kesempatan dalam mengelola dan membangun pariwisata, baik secara langsung maupun tidak langsung yang memiliki keterkaitan dengan industri atau usaha pariwisata, sehingga distribusi keuntungan merata kepada komunitas di pedesaan/ pesisir dan pulau-pulau kecil (Putra 2015). Dengan demikian CBT merupakan suatu pendekatan pembangunan pariwisata yang menekankan pada peran aktif masyarakat lokal (baik yang terlibat langsung dalam industri pariwisata maupun tidak). Pelibatan tersebut dalam bentuk memberikan kesempatan (akses) dalam manajemen dan pembangunan pariwisata yang berujung pada pemberdayaan masyarakat, termasuk dalam pembagian keuntungan dari kegiatan pariwisata (Putra, 2015). Bentuk perhatian yang kritis tersebut adalah gagasan terhadap pembangunan pariwisata yang seringkali mengabaikan hak masyarakat lokal di daerah tujuan wisata (Hadiwijoyo, 2012).

Dalam Peraturan Menteri Kebudayaan dan Pariwisata No: KM.67/ UM.o01/MKP/2004, Tentang Pedoman Umum Pengembangan Pariwisata di Pulau-pulau Kecil, dijelaskan tentang prinsip-prinsip pengembangan pariwisata yang salah satunya disinggung tentang prinsip partisipasi masyarakat. Dimana proses pelibatan masyarakat, baik secara aktif maupun pasif, harus dimulai sejak tahap perencanaan hingga tahap pengelolaan dan pengembangan. Hal ini akan menumbuhkan tanggungjawab dan rasa memiliki yang akan menentukan keberhasilan dan keberlanjutan pengembangan pariwisata di pulau-pulau kecil tersebut.

Kontribusi yang cukup besar dari sektor pariwisata, menyebabkan pemerintah menjadikan sektor pariwisata sebagai sektor pendukung pembangunan nasional dan penggerak ekonomi rakyat. Potensi wisata yang 
cukup besar serta sarana yang relatif tersedia di Indonesia diharapkan dapat mengembangkan dan memaksimalkan potensi yang dimilikinya dengan tujuan untuk meningkatkan kesejahteraan masyarakat.

Hal ini kemudian menjalar pada pemerintahan di daerah, termasuk Kota Makassar, Provinsi Sulawesi Selatan. Terbitnya Undang - Undang Nomor 22 Tahun 1999 Jo. Undang - Undang Nomor 32 tahun 2004 tentang Otonomi Daerah dan Undang - Undang Nomor 25 tahun 1999 Jo. Undang - Undang Nomor 33 tahun 2004 tentang Perimbangan Keuangan antara Pusat dan Daerah merupakan peluang emas bagi pemerintah Kota Makassar untuk mengelola berbagai potensi daya tarik wisata sebagai sumber pendapatan daerah dan perluasan kesempatan kerja. Pemerintah Kota Makassar diharapkan dari kesiapan, kemampuan teknis dan pengelolaannya dapat member konstribusi positif pada sektor pariwisata.

Kemampuan sumber daya manusia yang terbatas di bidang pengelolaan pariwisata menjadi isu utama dalam pengembangan pariwisata Pulau Samalona. Hal tersebut telihat dari penataan pantai dan fasilitas penunjang yang tidak tertata rapi. Selain itu, jarangnya pelatihan tentang kepariwisatan, terutama hospitality services kepada masyarakat setempat, sehingga dalam memberikan pelayanan ke wisatawan belum maksimal.

Pulau Samalona merupakan salah satu destinasi wisata di Kota Makassar selain Pulau Kayangan dan pulau-pulau lain yang berada di daerah teritorial Kota Makassar. Karena itu perlunya strategi yang efektif guna pengembangan wisata Pulau Samalona dengan memberdayakan masyarakat lokal sebagai pelaku industri pariwisata (pemilik, pengelola dan karyawan) sehingga destinasi pariwisata Pulau Samalona menjadi bagian dari sumber penghidupan bagi masyarakat lokal. Pulau Samalona merupakan destinasi pariwisata yang potensial untuk dikembangkan karena mengingat letak geografisnya berada tidak jauh dari pusat Kota Makassar (6,8 km) sehingga memudahkan wisatawan untuk berkunjung ke destinasi tersebut. Oleh karena itulah, maka untuk ke depan agar mampu bersaing, perlu dirumuskan secara matang suatu konsep pengembangan yang berpihak pada kepentingan dan kesejahteraan masyarakat.

Berdasarkan latar belakang permasalahan, maka dalam kajian ini lebih difokuskan pada upaya pengembangan pariwisata di Pulau Samalona dengan lebih mengedepankan konsep pengembangan pariwisata berbasis masyarakat, sehingga diharapkan mampu memberikan manfaat yang signifikan untuk kesejahteraan masyarakat setempat secara merata dan berkelanjutan. Untuk mengkaji mengenai pengembangan pariwisata berbasis masyarakat di Pulau Samalona, maka penelitian ini dilakukan terhadap aktivitas pariwisata di Pulau Samalona ditinjau dari potensi daya tarik serta pengembangannya dalam pemberdayaan masyarakat lokal. Sebab itu tujuan penelitian adalah; (1) Mengidentifikasi potensi dan daya 
tarik wisata, (2) Mengkaji sejauh mana partisipasi masyarakat lokal dan (3) Memformulasikan strategi pengembangan pariwisata berbasis masyarakat di Pulau Samalona, Kota Makassar.

\section{Teori dan Metode}

Terdapat tiga teori yang digunakan dalam penelitian ini. Teori tersebut antara lain: (1) Teori siklus hidup destinasi (tourism area life cycle) yang diperkenalkan Butler (1980) digunakan sebagai alat untuk memahami evolusi dari produk dan destinasi pariwisata; (2) Teori perencanaan yang digunakan untuk merumuskan strategi dalam pengembangan pariwisata berbasis masyarakat di Pulau Samalona; dan (3) Teori partisipasi digunakan untuk menguraikan bentuk-bentuk partisipasi masyarakat dalam proses atau aktifitas pariwisata di Pulau Samalona, baik secara langsung maupun tidak langsung dalam pengelolaan usaha jasa pariwisata.

Perencanaan merupakan pengorganisasian masa depan untuk mencapai tujuan tertentu (Inskeep, 1991). Menurut Sujarto (dalam Paturusi 2008), definisi perencanaan adalah suatu usaha untuk memikirkan masa depan (cita-cita) secara rasional dan sistematik dengan cara memanfaatkan sumber daya yang ada serta seefesien dan seefektif mungkin. Perencanaan adalah suatu proses pembuatan keputusan yang berkaitan dengan masa depan suatu destinasi atau atraksi wisata. Ini merupakan suatu proses dinamis dalam penentuan tujuan, yang secara bersistem mempertimbangkan berbagai alternatif tindakan untuk mencapai tujuan serta implementasinya terhadap alternatif yang dipilih dan evaluasinya. Proses perencanaan mempertimbangkan lingkungan politik, fisik, sosial, dan ekonomi sebagai suatu komponen yang saling terkait dan tergantung dengan yang lainnya (Paturusi, 2008:26).

Ridwan (2012:39-52) mengemukakan bahwa ada lima pendekatan perencanaan pengembangan pariwisata yang perlu diketahui dan diaplikasikan dalam pembangunan dan pengembangan pariwisata, yaitu: (1) pendekatan pemberdayaan masyarakat lokal, (2) pendekatan berkelanjutan, (3) pendekatan kesisteman, (4) pendekatan kewilayahan, dan (5) pendekatan dari sisi penawaran (supply) dan permintaan (demand).

Menurut Tosun (2000) partisipasi dapat membuat masyarakat, penduduk melakukan berbagai kegiatan, baik itu berskala lokal maupun nasional. Partisipasi yang dilakukan masyarakat berbeda-beda tingkatannya, akibat dari perbedaan skala kegiatan. Partisipasi itu antara lain, partisipasi karena paksaan (manipulative participation), partisipasi dengan kekuasaan dan ancaman (coercive participation), partisipasi karena adanya dorongan (indiced participation), partisipasi yang bersifat pasif (passive participation) dan partisipasi secara spontan (spontaneous participation).

Teknik pengumpulan data dalam penelitian ini dilakukan dengan 
tiga cara yakni (1) observasi ke lokasi penelitian untuk merekam perilaku atau kegiatan masyarakat yang selanjutnya diolah untuk mendapatkan data penelitian. Pengamatan terhadap lokasi penelitian dilakukan dengan mengamati secara langsung potensi dan daya tarik wisata, aspek sarana dan prasarana serta aspek fisik di Pulau Samalona, (2) wawancara mendalam (indepth interview) untuk mengumpulkan data secara detail dari informan dan (3) studi pustaka (dokumen) digunakan untuk memperoleh data langsung di tempat penelitian, meliputi buku-buku yang relevan, peraturan-peraturan, laporan kegiatan, foto-foto, arsip, manuskrip dan data yang relevan dengan penelitian sebagai pelengkap dari data hasil wawancara dengan informan yang telah ditentukan sebelumnya.

Pengolahan data dilakukan dengan tahapan sebagai berikut; (1) mengorganisasi dan editing data, yaitu melakukan penyusunan data berdasarkan tipologi satuan data dengan mempelajari secara seksama seluruh jenis data yang telah terkumpul dari hasil observasi, wawancara mendalam dan studi pustaka (dokumen), (2) menganalisis data, dan selanjutnya melakukan interpretasi data untuk mendapatkan simpulan. Teknik analisis data yang digunakan adalah deskriptif kualitatif dan Analisis SWOT, selanjutnya data disajikan dalam bentuk naratif dan dalam bentuk tabel.

\section{Gambaran Umum Pulau Samalona}

Pulau Samalona merupakan sebuah pulau kecil yang terletak di Kecamatan Ujung Pandang, Kota Makassar, Provinsi Sulawesi Selatan. Jaraknya sekitar 6,8 kilometer dari kota Makassar. Pulau Samalona secara administratif termasuk wilayah Kota Makassar, Provinsi Sulawesi Selatan. Pulau Samalona merupakan salah satu pulau yang berada di Kepulauan Spermonde sehingga memiliki potensi yang besar dalam pengembangan aktivitas kepariwisataan. Secara administratif luas wilayah Pulau Samalona yaitu 2,34 Ha, dengan batas wilayah; sebelah utara berbatasan dengan Pulau Kayangan, sebelah timur berbatasan dengan Pulau Lae-lae, sebelah selatan dan barat berbatasan dengan Selat Makassar (Profil Pulau Samalona Tahun, 2014).

Salah satu faktor penting dalam pengembangan sebuah destinasi wisata adalah tersedianya Aksesibilitas (Accessibility) menuju ke destinasi tersebut. Berdasarkan hasil observasi langsung yang dilakukan di lapangan, peneliti menemukan bahwa akses menuju ke Pulau Samalona bisa ditempuh melalui banyak tempat penyeberang seperti; Pelabuhan Paotere akan tetapi sebagian besar wisatawan menggunakan dermaga Popsa yang berada di depan Benteng Rotterdam sebagai tempat penyeberangan yang populer dan mudah diakses.

Dermaga penyeberangan Popsa menjadi akses utama yang dilalui 


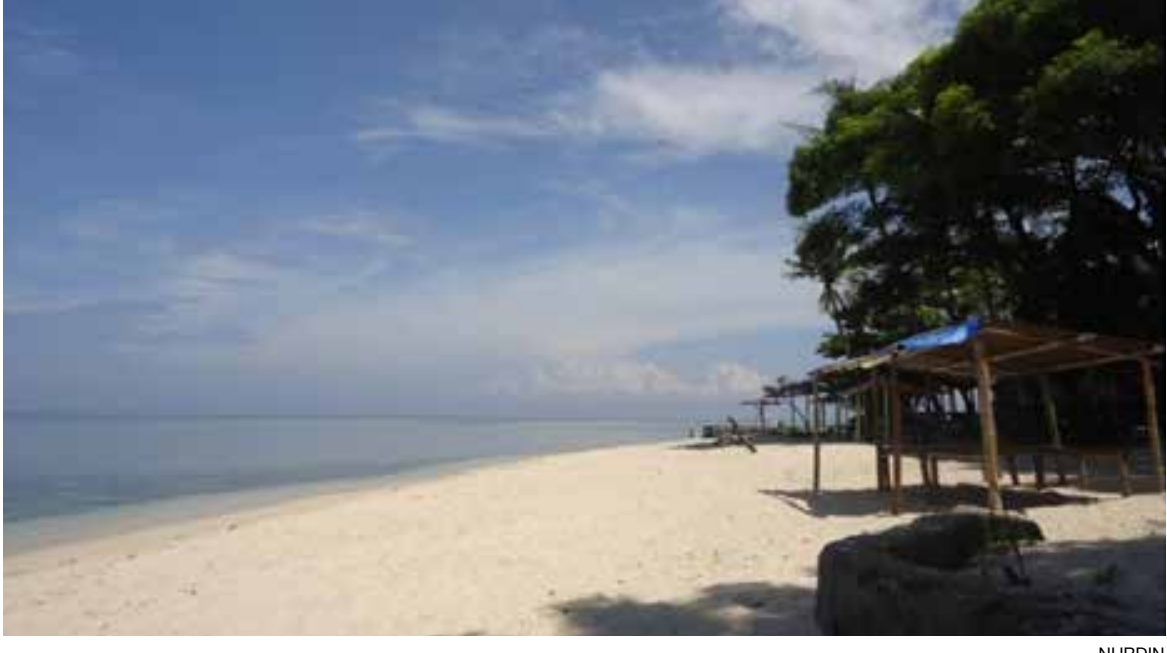

Foto 1. Potensi Pantai di Pulau Samalona

wisatawan yang ingin ke Pulau Samalona dengan pertimbangan bahwa; Letak dermaga Popsa yang dekat dengan Pantai Losari dan salah satu destinasi wisata sejarah Benten/Fort Rotterdam,serta dekat dengan akomodasi pariwisata dan akses jalan tol Reformasi yang menghubungkan ke Bandara Hasanuddin.

\section{Potensi Daya Tarik Pulau Samalona}

Potensi wisata menurut Mariotti dalam Yoeti (1983) adalah segala sesuatu yang terdapat di daerah tujuan wisata, dan merupakan daya tarik agar orang-orang mau datang berkunjung ke tempat tersebut. Wisnawa (2011) juga menjelaskan bahwa potensi wisata adalah sesuatu yang dapat dikembangkan menjadi daya tarik sebuah destinasi wisata. Dalam penelitian ini potensi wisata dibagi menjadi 2 macam, yaitu: potensi alam dan potensi sosial budaya.

\subsection{Potensi Alam}

Potensi alam yang dimaksud adalah keadaan dan jenis flora dan fauna suatu daerah, bentang alam suatu daerah, misalnya pantai, hutan, dan lainlain (keadaan fisik suatu daerah). Kelebihan dan keunikan yang dimiliki oleh alam jika dikembangkan dengan memperhatikan keadaan lingkungan sekitarnya niscaya akan menarik wisatawan untuk berkunjung ke destinasi wisata. Potensi daya tarik alam yang dimiliki Pulau Samalona berupa; Pantai dengan pasir putih, Laut dengan biota laut dan karangnya serta panorama matahari terbit (sunrise) dan terbenam (sunset)

Pantai di Pulau Samalona merupakan salah satu potensi dan daya tarik yang sangat layak dikembangkan dalam pengembangan pariwisata berbasis masyarakat. Tampak pantai yang indah dengan pasir putihnya yang bagus untuk wisatawan yang senang berjemur, voli pantai dan berbagai olahraga dan aktivitas di pantai lainnya, atau wisatawan yang senang menikmati mandi matahari (sunbathing) dengan pemandangan laut (Foto 1). 
Selain potensi pantai terdapat pula potensi laut yang masih alami dengan berbagai aktivitas wisata yang bisa dilakukan oleh para wisatawan yang berkunjung ke Pulau Samalona. Laut biru dengan beraneka biota lautnya yang potensial untuk atraksi wisata memancing (fishing), keindahan pemandangan bawah laut seperti terumbu karangnya sangat cocok untruk wisatawan yang senang snorkeling maupun diving. Hal tersebut sesuai dengan hasil wawancara mendalam (in-depth interview) dengan Kasub Perencanaan Dinas Pariwisata dan Ekonomi Kreatif Kota Makassar yang menyebutkan bahwa potensi pantai dan laut merupakan potensi yang sangat bagus untuk pengembangan pariwisata berbasis masyarakat dimana masyarakat bisa memperoleh pendapat bukan hanya dari hasil melaut.

Beragamnya potensi daya tarik wisata di Pulau Samalona merupakan suatu kekuatan untuk pengembangan pariwisata. keindahan saat matahari terbit (sunrise) dan terbenam (sunset) menjadi momen yang menarik bagi para wisatawan terutama bagi wisatawan yang memiliki hobi pemotretan (photography).

\subsection{Potensi Sosial budaya}

Potensi budaya adalah semua hasil cipta, rasa dan karsa manusia baik berupa adat istiadat, kerajinan tangan, kesenian, peninggalan bersejarah nenek moyang berupa bangunan, monument, dan lain-lain. Masyarakat di Pulau Samalona berasal dari suku Bugis Makassar. Wujud dari kebudayaan di Pulau Samalona ini terlihat dalam bahasa, perkawinan, kepercayaan dan sistem kemasyarakatannya. Budaya mempunyai peran penting dalam membuat produk wisata mempunyai keunikan dan diferensiasi tersendiri. Budaya juga menyediakan elemen 'hidup' dari suatu produk sehingga menghasilkan pengalaman tersendiri yang kian diminati oleh wisatawan.

Potensi sosial budaya tercermin dari keramah-tamahan masyarakat di Pulau Samalona dengan sistem kekerabatan yang sangat erat dan ini menjadi daya tarik tersendiri. Wisatawan lebih senang mengunjungi suatu masyarakat yang ramah dan bisa dikunjungi oleh wisatawan asing tetapi dalam masyarakat ini mereka menerima kunjungan wisatawan dengan senang hati. Potensi lain berupa; adat istiadat masyarakat, rumah adat BugisMakassar, kesenian tradisional masyarakat. Ada berbagai macam kesenian tradisional masyarakat bugis Makassar salah satunya adalah tari-tarian, adapun beberapa tarian yang sering dipertunjukkan di Pulau Samalona, seperti; tari pakarena dan tari ma'raga.

Tari Pakarena adalah tarian tradisional dari makasar, Sulawesi Selatan, Indonesia. Pada abad 20, tari ini keluar dari tradisi istana dan menjadi pertunjukan populer.Tarian ini seringkali dipentaskan di sejumlah acara, seperti pernikahan, ritual penobatan dan sunatan.Tari ini sangat energik, terkadang begitu hingar bingar oleh musik, namun diiringi oleh tarian yang 


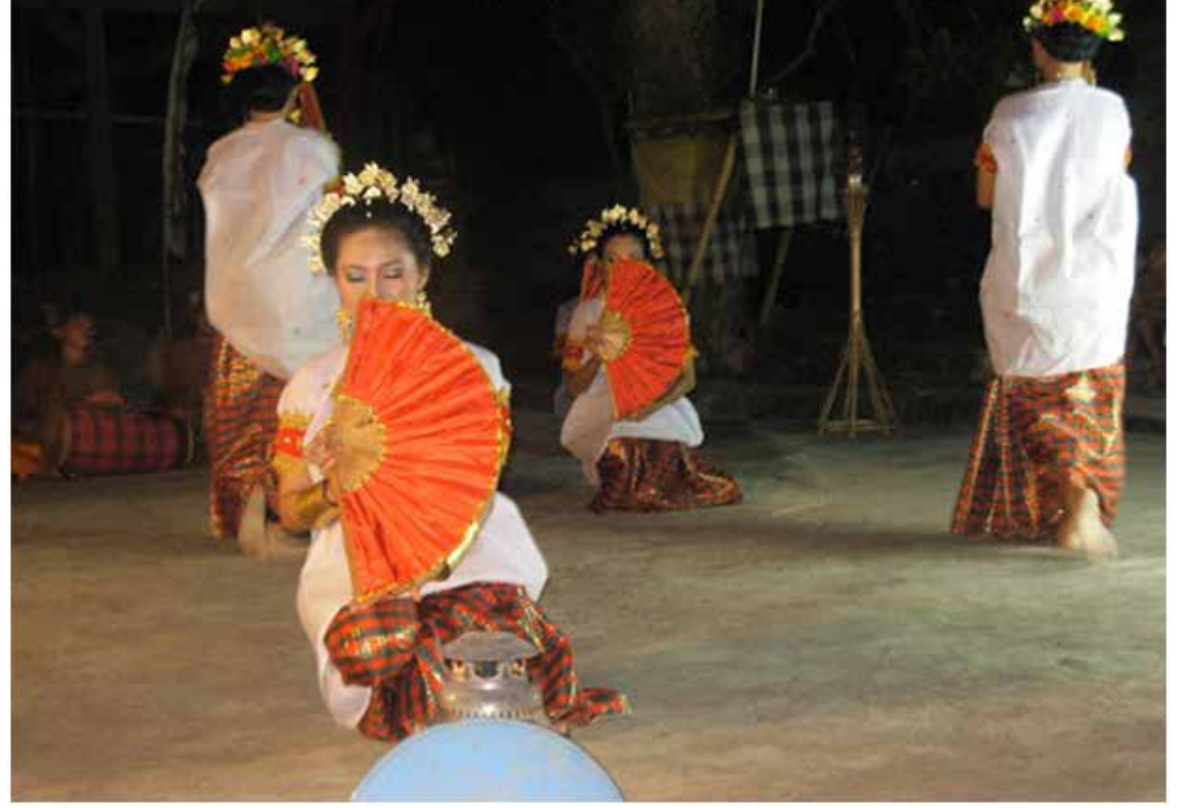

NURDIN

Foto 2. PertunjukanTari Pakarena di Pulau Samalona

sangat lambat lemah gemulai dari para penari wanita muda. Dua kepala drum (gandrang) dan sepasang instrument alat semacam suling (puik-puik) mengiringi dua penari (Foto 2).

Tari ma'raga/Sepak raga sudah ada pada zaman kerajaan Gowa dan dilestarikan sampai sekarang. Tari ini biasa dimainkan pada acara penjemputan, peresmian, festival, perkawinan dan acara-acara adat lainnya. Paraga atau memainkan bola raga dengan konstruksi bola berpindah-pindah dari kaki ke kaki adalah aktualisasi gerak bermain atau keadaan senang atau dalam bahasa Makassar dikenal dengan istilah a'rannu-rannu dengan bermain bola raga (ayaman rotan). Tarian ini dimainkan oleh 6 (enam) orang laki-laki dengan pakaian adat passapu ', dipadu dengan baju kantiu dengan celana barocci, yang diiringi dengan musik tradisional berirama manca (semacam ketukan cepat yang mengiringi acara pencak silat), segalanya untuk memperlihatkan estetika hiburan keterampilan/atraksi dalam memainkan bola takraw (Foto 3).

Tokoh masyarakat / ketua adat (Daeng Ru'rung) mengungkapkan bahwa tarian Pakarena berawal dari kisah mitos perpisahan penghuni boting langi (negeri kayangan) dengan penghuni lino (bumi) zaman dulu.Unsur budaya ini bisa diangkat sebagai salah satu daya tarik wisata karena potensi nilainilai budaya masyarakat tercermin dari kesenian yang mereka pertontonkan. Berdasarkan hasil wawancara tersebut Tari-tarian tradisional Makassar dapat dilestarikan dan memberikan penghidupan bagi para seniman, sehingga potensi ini dapat dikembangkan menjadi suatu daya tarik wisata budaya.

Dengan adanya potensi tersebut maka akan melengkapi daya tarik wisata yang ada di Pulau Samalona termasuk potensi alamnya, sehingga wisatawan 
keamanan dan kenyamanan lingkungan Pulau serta menjaga kebersihan dan melestarikan lingkungan pulau.

Kenyamanan dan keamanan menjadi kondisi yang sangat penting dalam industri pariwisata. Aspek tersebut pada dua dekade terakhir telah menjadi isu yang semakin besar dan mempunyai dampak yang sangat besar terhadap keberlangsungan aktivitas perjalanan dan pariwisata (István Kövári dan Krisztina Zimányi, 2011). Ancaman kenyamanan dan keamanan wisatawan dapat dipengaruhi dan disebabkan oleh beragam faktor, seperti aksi teroris, konflik lokal, bencana alam, perilaku sosial masyarakat dan penyakit menular sehingga hal tersebut dapat menyebabkan menurunnya rasa aman bagi wisatawan. Kenyamanan dan keamanan bagi wisatawan merupakan salah satu faktor yang menentukan keputusan untuk melakukan suatu perjalanan ke suatu destinasi pariwisata.

Salah satu tokoh masyarakat (Daeng Sikki') mengungkapkan bahwa keamanan di Pulau Samalona bisa dikatakan aman dan terkendali karena mengingat daerah ini adalah pulau dan terisolasi sehingga gangguan dari luar yang tidak diinginkan tidak akan terjadi. Gangguan lain yang bisa menjadi ancaman adalah konflik internal masyarakat pulau juga bisa terkontrol, sebab masyarakat di Pulau Samalona masih memiliki hubungan kekerabatan yang sangat dekat. Jadi masyarakat pulau merasa aman dan nyaman dengan begitu wisatawan pun akan merasa nyaman selama berwisata di Pulau Samalona. Dengan kondisi tersebut akan menjadi kekuatan tersendiri Pulau Samalona dalam pengembangan pariwisata dan secara khusus menunjang pengembangan pariwisata berbasis masyarakat.

"keamanan Pulau Samalona bisa saya katakan sangat aman karena inikan pulau, jadi orang yang datang dan pergi bisa diketahui. Apalagi masyarakat pulau rata-rata masih memiliki hubungan kekerabatan yang sangat dekat jadi pertengkaran antar warga bisa terkendali sehingga masyarakat merasa aman dan nyaman, begitupun wisatawan akan nyaman selama di pulau, saya juga informasikan bahwa setiap malam warga ronda dan berkeliling di pulau dan itu kami lakukan secara bergiliran.” (Wawancara, 20 Februari 2015)

Kondisi aman yang sudah terciptan harus dihargai dan diapresiasi sebagai salah satu bentuk partisipasi masyarakat dalam pengembangan pariwisata berbasis masyarakat di Pulau Samalona. Walaupun hal tersebut masyarakat tidak secara langsung berpartisipasi dalam aktivitas kepariwisataan. Menjaga keamanan di pulau juga dilakukan oleh masyarakat dengan melakukan patroli keliling pada saat malam, sehingga keamanan dan kenyaman wisatawan sangat terjamin.

Lingkungan merupakan sarana utama yang harus diperhatikan bagi berhasilnya pengembangan pariwisata. Kebersihan lingkungan adalah kebersihan tempat tinggal, tempat bekerja, dan berbagai sarana umum 
lainnya, tidak sulit menjaga kebersihan lingkungan ada banyak macam cara untuk menjaga kebersihan lingkungan misalnya dengan membuang sampah pada tempatnya serta menata lingkungan sekitar sehingga tampak bersih dan rapi. Beberapa faktor yang mempengaruhi timbulnya sampah adalah jumlah penduduk, sistem pengumpulan/pembuangan sampah, faktor geografis dan kebiasaan masyarakat.

Kepala dusun Pulau Samalona (Daeng Lallo') mengungkapkan bahwa masyarakat berpartisipasi dalam menjaga kebersihan lingkungan pulau walaupun pemilahan sampah belum dilakukan dan ini menjadi kendala juga bagi masyarakat karena tempat pengumpulan/pembuangan sampah dan pengangkutan sampah di Pulau belum dibuat sistem atau pengelolaan yang baik dan tepat.

"Masyarakat ikut menjaga kebersihan pulau paling tidak lingkungan rumah mereka masing-masing, walaupun kami terkendala pengumpulan dan pembuangan sampah karena di pulau kami tidak tau mau dibuang ke mana sampahnya jadi kami bakar saja..... Kalau kami angkut lagi melaui perahu bisa tapi tempat pembuangan di Makassar jauh jari dermaga dan pasti memerlukan bahan bakar lagi. (Wawancara, 21 Februari 2015)

Partisipasi masyarakat baik secara langsung maupun tidak langsung mejadi penunjang dalam pengembangan pariwisata berbasis masyarakat di Pulau Samalona. Sehingga ini bisa menjadi pertimbangan bagi pemerintah dalam mendukung pengembangan tersebut, dengan membuat regulasi dan program yang tepat yang dapat memberikan keuntungan bagi masyarakat setempat.

\section{Strategi Pengembangan Pariwisata Berbasis Masyarakat di Pulau Samalona}

Untuk dapat merumuskan strategi pengembangan yang tepat terhadap suatu destinasi pariwisata maka, perlu diketahui fase-fase atau siklus hidup area wisata. Sesuai dengan teori yang digunakan dalam penelitian ini yaitu teori siklus hidup destinasi yang diadaptasi dari Butler (1980), terdapat tujuh fase-fase dalam siklus evolusi destinasi pariwisata yaitu: exploration (penemuan), involvement (keterlibatan), development (pembangunan), consolidation (konsolidasi), stagnation (stagnasi), decline (penurunan), dan rejuvenation (peremajaan).

Berdasarkan hasil observasi dan wawancara mendalam dengan semua narasumber (17 narasumber) serta dilengkapi dengan data jumlah kunjungan wisatawan dari tahun 2013 dan 2014 terus mengalami peningkatan. Data penyeberangan di dermaga Popsa menunjukkan bahwa terjadi peningkatan Jumlah kunjungan dari tahun 2013 sejumlah 1544 wisatawan dan mengalami peningkatan di tahun 2014 sejumlah 1877 wisatawan. 
Mengacu pada teori siklus hidup destinasi maka Pulau Samalona berada pada posisi involment (keterlibatan), hal tersebut terlihat dari adanya peningkatan kunjungan wisatawan baik wisatawan nusantara maupun wisatawan mancanegara. Meningkatnya jumlah kunjungan wisatawan tersebut mendorong penduduk lokal menawarkan fasilitas secara ekslusif kepada wisatawan. Kontak dengan masyarakat lokal menyesuaikan pola sosialnya untuk mengakomodasi perubahan kondisi ekonomi akibat keberadaan wisatawan, dengan menyediakan makanan dan minum serta penginapan.

Kondisi lingkungan internal Pulau Samalona terdiri dari beberapa faktor yang dapat menjadi kekuatan dan kelemahan dalam pengembangan pariwisata berbasis masyarakat. Faktor yang dapat menjadi kekuatan di antaranya; (1) keindahan alam, (2) sikap ramah-tamah masyarakat lokal, (3) sikap toleransi dan (4) keunikan tradisi dan budaya masyarakat lokal. faktor yang menjadi kelemahan adalah; (1) sumber daya manusia dan (2) manajemen destinasi.

Kondisi lingkungan eksternal Pulau Samalona terdiri beberapa faktor yang dapat menjadi peluang dan ancaman dalam pengembangan pariwisata berbasis masyarakat. Faktor yang dapat menjadi peluang diantaranya adalah; (1) kemajuan teknologi dan telekomunikasi, (2) jarak pulau samalona dengan bandara internasional hasanuddin makassar, (3) jarak pulau samalona dengan kota makassar dan (4) aturan (code of conduct). Faktor yang menjadi kelemahannya adalah Kurangnya Kesadaran Masyarakat dalam menjaga Kebersihan dan Kelestarian Lingkungan.

Berdasarkan kondisi lingkungan internal dan eksternal Pulau Samalona serta jumlah kunjungan wisatawan, maka strategi umum (grand strategy) yang bisa diterapkan adalah strategi penetrasi pasar dan pengembangan produk wisata. Strategi penetrasi pasar adalah strategi memperluas pasar (market share) suatu produk atau jasa melalui usaha-usaha pemasaran yang lebih besar (Umar, 2005).

Berdasarkan kekuatan, kelemahan, peluang dan ancaman dalam pengembangan pariwisata berbasis masyarakat di Pulau Samalona, maka melalui matriks SWOT akan ditemukan beberapa strategi khusus yang dapat mendukung kelayakan pengembangan pariwisata berbasis masyarakat di Pulau Samalona. Alternatif pengembangan pariwisata berbasis masyarakat di Pulau Samalona sebagai strategi khusus, yang merupakan opsi pengembangan yang dapat diterapkan yaitu; (1) Strategi pengembangan destinasi pariwisata, (2) Strategi pengembangan daya tarik wisata, (3) Strategi peningkatan kualitas lingkungan, (4) Strategi pengembangan pariwisata berkelanjutan, (5) Strategi pengembangan promosi destinasi pariwisata, (6) Strategi pengembangan sumber daya manusia, dan (7) Strategi pengembangan kelembagaan dan manajemen destinasi. 


\section{Simpulan}

Potensi Pulau Samalona sebagai destinasi pariwisata berbasis masyarakat dapat dikembangkan menjadi daya tarik sebagai pendukung dalam pengembangan tersebut adalah potensi alam dan potensi sosial budaya. Potensi alam Pulau Samalona terdiri dari keindahan laut dan pantainya dengan hamparan pasir putihnya yang sangat eksotis serta panorama matahari terbit (sunrise) dan matahari terbenam (sunset). Potensi sosial budaya terdiri dari adat istiadat masyarakat, bangunan atau rumah adat bugis-makassar dan kesenian tradisional bugis-makassar di Pulau Samalona.

Partisipasi masyarakat baik itu secara langsung maupun tidak lansung dapat menunjang pengembangan pariwisata berbasis masyarakat di Pulau Samalona. Hal tersebut menjadi kekuatan dalam pengembangan meskipun terdapat beberapa kendala diantaranya; sumber daya manusia, manajemen destinasi pariwisata, masih rendahnya kesadaran masyarakat dalam menjaga kebersihan dan kelestarian lingkungan.

Strategi yang tepat dan dapat diterapkan sebagai berikut; Strategi pengembangan destinasi pariwisata, Strategi pengembangan daya tarik wisata, Strategi peningkatan kualitas lingkungan, Strategi pengembangan pariwisata berkelanjutan, Strategi promosi destinasi pariwisata, Strategi pengembangan sumber daya manusia dan Strategi pengembangan kelembagaan dan manajemen destinasi.

\section{Saran}

Perlu dilakukan pengembangan pariwisata berbasis masyarakat di Pulau Samalona. Dengan Peningkatan sumber daya manusia khususnya di sektor pariwisata, baik kualitas maupun kuantitasnya. Hal tersebut sangat perlu dilakukan untuk meningkatkan kualitas pelayanan serta menunjang pengelolaan destinasi pariwisata yang baik dan efisien.

Sosialisasi mengenai gerakan sadar wisata serta kampanye tentang kebersihan dan kelestarian lingkungan, hal ini dimaksudkan sebagai upaya untuk meningkatkan kesadaran masyarakat untuk lebih perduli terhadap pentingnya menjaga kebersihan dan kelestarian lingkungan. Gerakan sadar wisata diperlukan untuk meningkatkan pemahaman masyarakat mengenai pariwisata sehingga program sapta pesona dapat terlaksana dengan baik di Pulau Samalona, di mana dalam sapta pesona tersebut terdapat upaya pelestarian lingkungan yaitu dengan tetap menjaga kebersihan dan kelestarian lingkungan dengan program bersih pantai minimal sekali seminggu dengan melibatkan semua pihak termasuk wisatawan. Penerapan konsep wisata ramah lingkungan juga diperlukan untuk mendukung pengembangan pariwisata berbasis masyarakat yang berkelanjutan. Selain hal tersebut, masih perlu dilakukan pembinaan terhadap pemilik pemilik penginapan/pondok wisata dan warung-warung makan yang ada di Pulau 
Samalona.

Perlu penelitian lanjutan terkait pengembangan daya tarik wisata, analisis kajian perkembangan pariwisata di Pulau Samalona, dampak pariwisata pada aspek ekonomi dan sosial budaya masyarakat Pulau Samalona, analisis dampak lingkungan dari kegiatan kepariwisataan di Pulau Samalona, serta penelitian terkait lainnya.

\section{Ucapan Terima Kasih}

Penulis menyampaikan terima kasih kepada Dr. Ir. Syamsul Alam Paturusi, MSP dan Dr. Dewa Putu Oka Prasiasa, A.Par,. MM selaku pembimbing utama dan pendamping. Terima kasih yang setulusnya penulis sampaikan kepada Prof. Dr.I Nyoman Darma Putra, M.Litt selaku Ketua Program Studi Magister Kajian Pariwisata Program Pascasarjana Universitas Udayana atas bimbingan dan saran demi kesempurnaan tulisan ini.

\section{Daftar Pustaka}

Arnstein, Sherry R. 1969. "A Ladder of Citizen Participation" dalam Journal of the American Planning Association, Vol. 35, No. 4, Juli, Hal. 216-224.

Butler, R.W. 1980. The Concept of Tourism Area Cycle of Evolution: Implications for the Management of resources. Kanada: University of Western Ontario.

Hadiwijoyo, Suryo S. 2012. Perencanaan Pariwisata Pedesaan Berbasis Masyarakat (Sebuah Pendekatan Konsep). Yogyakarta: Graha Ilmu.

Husein, Umar. 2001. Strategic Management in Action: Konsep, Teori dan Teknik Menganalisis Manajemen Strategis. Jakarta: PT. Gramedia PustakaUtama.

Inskeep, Edward. 1991. Tourism Planning an Integrated and Sustainable Development Approach. New York: Van Nostrand Reinhold.

Kemen LH. 2003. "Pengembangan Wisata Ramah Lingkungan Berbasis Masyarakat", http://www.menlh.go.id/pengembangan-wisata-ramah-lingkungan-berbasismasyarakat/, Diakses 10 Februari 2014

Kövári, István dan Zimányi, Krisztina. 2011. Safety and Security in the Age of Global Tourism (The changing role and conception of Safety and Security in Tourism). Budapest: Agroinform Publishing House.

Paturusi, Syamsul Alam. 2008. Perencanaan Kawasan Pariwisata. Denpasar: Udayana University Press.

Peraturan Menteri Kebudayaan dan Pariwisata No: KM.67/ UM.001/MKP/2004 Tentang Pedoman Umum Pengembangan Pariwisata di Pulau-Pulau Kecil.

Peraturan Pemerintah RI No. 50 Tahun 2011 tentang Rencana Induk Pembangunan Kepariwisataan Nasional (Ripparnas).

Putra, I Nyoman Darma. 2015. Pariwisata Berbasis Masyarakat Model Bali. Denpasar: Buku Arti.

Ridwan, Muhammad. 2012. Perencanaan dan Pengembangan Pariwisata. Jakarta: PT. Sofmedia 
Rangkuti, Freddy. 2009. Analisis SWOT Teknik Membedah Kasus Bisnis Reorientasi Konsep Perencanaan Strategis Untuk Menghadapi Abad 21. Jakarta: PT. Gramedia Pustaka.

Tosun, C. 2000. Limits to community participation in the tourism development process in developing countries. Turkey: Bilkert University.

Umar, Husein. 2005. Metode Penelitian untuk Skripsi, Tesis dan Bisnis. Jakarta: PT. Raja Grafindo Persada.

Undang - Undang RI Nomor 10 Tahun 2009 Tentang Kepariwisataan.

Yoeti, Oka A. 2002. Perencanaan Strategis Pemasaran Dearah Tujuan Wisata. Jakarta: PT Pradnya Paramita.

\section{Profil Penulis}

Nurdin menyelesaikan pendidikan Diploma IV (D4) pariwisata pada Sekolah Tinggi Pariwisata Tamalatea Makassar (2010), menyelesaikan Prodi Magister Kajian Pariwisata Universitas Udayana tahun 2016, dan saat ini menjadi dosen tetap serta menjabat Ketua bidang akademik pada kampus yang sama. Penulis juga aktif mengajar di beberapa kampus di Kota Makassar. 